\title{
Does hepatic impairment influence renal function parameters in liver cirrhosis?
}

\author{
Tingxue Song ${ }^{1}$, Zhe Jia ${ }^{2 *}$, Xiaozhong Guo ${ }^{1,3 *}$, Haitao Zhao ${ }^{4}$, Wenchun Bao ${ }^{1}$, \\ Dan Han ${ }^{1}$, Xinmiao Zhou ${ }^{5}$, Xingshun $\mathbf{Q i}^{3}$ \\ 'Postgraduate College, Liaoning University of Traditional Chinese Medicine, Shenyang, Liaoning Province, \\ China; \\ ${ }^{2}$ Section of Medical Service, General Hospital of Shenyang Military Area, Shenyang, Liaoning Province, China; \\ ${ }^{3}$ Liver Cirrhosis Study Group, Department of Gastroenterology, General Hospital of Shenyang Military Area, \\ Shenyang, Liaoning Province, China; \\ ${ }^{4}$ Medical Ethical Committee, General Hospital of Shenyang Military Area, Shenyang, Liaoning Province, China; \\ ${ }^{5}$ Postgraduate College, Jinzhou Medical University, Jinzhou, Liaoning Province, China
}

\section{TO THE EDITOR}

Renal function parameters are important for the evaluation of prognosis of liver cirrhosis patients..$^{[1]}$ Serum creatinine (SCr) is the most commonly used index for the clinical evaluation of renal function. Dynamic evaluation of $\mathrm{SCr}$ is one of the most important diagnostic criteria for acute kidney injury in liver cirrhosis. ${ }^{[2]}$ A systematic review showed that $\mathrm{SCr}$ was a powerful predictor of death in the decompensated patients with cirrhosis. ${ }^{[3]}$

Cystatin C is considered as an ideal endogenous marker reflecting the glomerular filtration rate, ${ }^{[4]}$ because the kidney is the only organ where Cystatin C filtrated and metabolized. Cystatin $C$ provided an early diagnosis of moderate renal impairment in patients with liver cirrhosis (especially Child-Pugh C). ${ }^{[5]}$ Evidence suggests that the diagnostic accuracy of Cystatin $\mathrm{C}$ is significantly better than that of $\mathrm{SCr}$ in patients with reduced glomerular filtration rate. ${ }^{[6]}$ Recent study found that Cystatin $\mathrm{C}$ might be a more accurate parameter for assessing the prognosis and mortality of liver cirrhosis. ${ }^{[7]}$ Similarly, in cirrhotic patients with ascites, the level cystatin $\mathrm{C}$ was an independent predictor of mortality and development of HRS-1. ${ }^{[8]}$

Serum $\beta 2$ microglobulin is another renal function parameter that correlates with glomerular filtration rate. A study showed that serum $\beta 2$ microglobulin concentration was significantly increased in patients with liver cirrhosis (especially non-alcoholic cirrhosis). ${ }^{[9]}$ Serum $\beta 2$ microglobulin level was elevated in HCV-related chronic liver disease, and may also be used as a marker for progression towards liver cirrhosis and hepatocellular carcinoma. ${ }^{[10]}$

Herein, we conducted a preliminary retrospective observational study to explore the influence of hepatic impairment on renal function parameters in patients with liver cirrhosis.

This single-center retrospective study was approved by the medical committee of General Hospital of Shenyang Military Area. The number of ethical approval is $\mathrm{k}$ (2017) 26. The patient written informed consent was not required. All the patients who were diagnosed with liver cirrhosis and consecutively treated by an attending physician, Dr. Xingshun Qi at the Department of Gastroenterology of the Shenyang General Hospital of Military Area from February 2016 to November 2017 were eligible. We collected the data regarding renal and hepatic function parameters, which were detected at the same time during hospitalization. The normal ranges of laboratory tests were: $\mathrm{SCr}$ (44-133 $\mu \mathrm{mol} / \mathrm{L})$, Cystatin C $(0-1.03 \mathrm{mg} / \mathrm{L})$ and serum $\beta 2$ microglobulin $(0.9-3 \mathrm{mg} / \mathrm{L})$. Statistical analyses were performed using SPSS version 20.0.0 software (SPSS Inc., Chicago, IL, USA). Continuous data were expressed as mean \pm standard deviation 
(SD) and median (range). Categorical data were expressed as frequency (\%). Spearman non-parametric tests and Pearson chi-square tests were used to perform the correlation analysis. Correlation coefficient was calculated. A two-tailed $P<0.05$ was considered to have a significantly statistical difference.

One hundred patients with liver cirrhosis were enrolled, of whom $64(64 \%)$ were male and $36(36 \%)$ were female. The average of age was $60.53 \pm 11.38$ years (range 32-88 years). SCr was detected for 224 times, and the average $\mathrm{SCr}$ concentration was $69.71 \pm 27.90$ (range 31.85-314.00). Cystatin $\mathrm{C}$ was detected for 223 times, and the average Cystatin C concentration was $1.22 \pm 0.69$ (range 0.44-6.00). Serum $\beta 2$ microglobulin was detected for 33 times, and the average serum $\beta 2$ microglobulin concentration was $3.00 \pm 1.28$ (range 1.56-7.19).

Correlation analyses of renal function indexes were summarized in Table 1 . SCr positively correlated with Cystatin C, serum $\beta 2$ microglobulin, total bilirubin, direct bilirubin, and pre-albumin. Cystatin $C$ positively correlated with serum $\beta 2$ microglobulin, total bilirubin, direct bilirubin, fucosidase, total bile acid, and total protein. Serum $\beta 2$ microglobulin positively correlated with prealbumin and total protein.

In conclusion, we found that hepatic impairment might marginally influence the renal function parameters in liver cirrhosis. We could not establish any parallel correlation of renal and hepatic function parameters in liver cirrhosis.

\section{Conflict of Interest}

The authors declare no conflict of interest.

\section{REFERENCES}

1. Garcia-Tsao G, Parikh CR, Viola A. Acute kidney injury in cirrhosis. Hepatology 2008;48:2064-77.

2. Angeli P, Gines P, Wong F, Bernardi M, Boyer TD, Gerbes A, et al. Diagnosis and management of acute kidney injury in patients with cirrhosis: revised consensus recommendations of the International Club of Ascites. Gut 2015;64:531-7.

3. D’Amico G, Garcia-Tsao G, Pagliaro L. Natural history and prognostic indicators of survival in cirrhosis: a systematic review of 118 studies. J Hepatol 2006;44:217-31.

4. Jovanović D, Krstivojević P, Obradović I, Durdević V, Dukanović L. Serum cystatin $\mathrm{C}$ and beta2-microglobulin as markers of glomerular filtration rate. Ren Fail 2003;25:123-33.

5. Gerbes AL, Gülberg V, Bilzer M, Vogeser M. Evaluation of serum cystatin $\mathrm{C}$ concentration as a marker of renal function in patients with cirrhosis of the liver. Gut 2002;50:106-10.

6. Kyhse-Andersen J, Schmidt C, Nordin G, Andersson B, Nilsson-Ehle P, Lindström V, et al. Serum cystatin C, determined by a rapid, automated particle-enhanced turbidimetric method, is a better marker than serum creatinine for glomerular filtration rate. Clin Chem 1994;40:1921-6.

7. Maiwall R, Kumar A, Bhardwaj A, Kumar G, Bhadoria AS, Sarin SK. Cystatin $\mathrm{C}$ predicts acute kidney injury and mortality in cirrhotics: A prospective cohort study. Liver Int 2017.

8. Seo YS, Park SY, Kim MY, Kim SG, Park JY, Yim HJ, et al. Serum cystatin $C$ level: An excellent predictor of mortality in patients with cirrhotic ascites. J Gastroenterol Hepatol 2018; 33:910-7.

9. Nakamura S, Takezawa Y, Maeda T. Serum beta 2-microglobulin in chronic liver diseases. Tohoku J Exp Med 1981;134:221-2.

10. Ouda SM, Khairy AM, Sorour AE, Mikhail MN. Serum Beta-2 Microglobulin: A Possible Marker for Disease Progression in Egyptian Patients with Chronic HCV Related Liver Diseases. Asian Pac J Cancer Prev 2015;16:7825-9.

How to cite this article: Song T, Jia Z, Guo X, Zhao H, Bao W, Han D, et al. Does hepatic impairment influence renal function parameters in liver cirrhosis? J Transl Intern Med 2018; 6: 90-2. 
Song et al.: Relationship between renal and hepatic function in liver cirrhosis

\begin{tabular}{|c|c|c|c|}
\hline Variables & No. groups of data & $\begin{array}{l}\text { Pearson coefficient or } \\
\text { Spearman coefficient }\end{array}$ & $P$ value \\
\hline \multicolumn{4}{|c|}{ Correlation analysis of serum creatine in patients of liver cirrhosis } \\
\hline Cystatin C (mg/L) & 223 & 0.31 & 0.000002 \\
\hline Serum $\beta 2$ microglobulin (mg/L) & 32 & 0.526 & 0.002 \\
\hline Total bilirubin $(\mu \mathrm{mol} / \mathrm{L})$ & 218 & 0.194 & 0.004 \\
\hline Direct bilirubin $(\mu \mathrm{mol} / \mathrm{L})$ & 218 & 0.163 & 0.016 \\
\hline Alanine aminotransferase $(\mathrm{U} / \mathrm{L})$ & 217 & -0.021 & 0.756 \\
\hline Aspartate aminotransferase $(\mathrm{U} / \mathrm{L})$ & 218 & -0.01 & 0.881 \\
\hline Alkaline phosphatase $(\mathrm{U} / \mathrm{L})$ & 218 & -0.07 & 0.305 \\
\hline Glutamyl transpeptidase (U/L) & 217 & -0.111 & 0.102 \\
\hline Fucosidase (U/L) & 217 & 0.12 & 0.078 \\
\hline Total bile acid $(\mu \mathrm{mol} / \mathrm{L})$ & 216 & 0.113 & 0.098 \\
\hline Pre-albumin (mg/L) & 204 & 0.164 & 0.019 \\
\hline Total protein (g/L) & 206 & 0.022 & 0.749 \\
\hline Albumin $(\mathrm{g} / \mathrm{L})$ & 207 & -0.018 & 0.8 \\
\hline PT (s) & 174 & 0.069 & 0.363 \\
\hline INR & 174 & 0.074 & 0.335 \\
\hline \multicolumn{4}{|c|}{ Correlation analysis of Cystatin C in patients liver cirrhosis } \\
\hline Serum $\beta 2$ microglobulin (mg/L) & 32 & 0.367 & 0.039 \\
\hline Total bilirubin $(\mu \mathrm{mol} / \mathrm{L})$ & 217 & 0.156 & 0.021 \\
\hline Direct bilirubin $(\mu \mathrm{mol} / \mathrm{L})$ & 217 & 0.146 & 0.032 \\
\hline Alanine aminotransferase $(\mathrm{U} / \mathrm{L})$ & 217 & -0.026 & 0.707 \\
\hline Aspartate aminotransferase $(\mathrm{U} / \mathrm{L})$ & 217 & 0.06 & 0.376 \\
\hline Alkaline phosphatase $(\mathrm{U} / \mathrm{L})$ & 217 & 0.027 & 0.688 \\
\hline Glutamyl transpeptidase (U/L) & 217 & -0.061 & 0.37 \\
\hline Fucosidase (U/L) & 217 & 0.139 & 0.04 \\
\hline Total bile acid $(\mu \mathrm{mol} / \mathrm{L})$ & 216 & 0.194 & 0.004 \\
\hline Pre-albumin (mg/L) & 204 & 0.033 & 0.641 \\
\hline Total protein $(g / L)$ & 205 & 0.161 & 0.021 \\
\hline Albumin (g/L) & 206 & -0.037 & 0.597 \\
\hline PT (s) & 173 & 0.065 & 0.399 \\
\hline INR & 173 & 0.058 & 0.45 \\
\hline \multicolumn{4}{|c|}{ Correlation analysis of serum ß 2 microglobulin in patients of liver cirrhosis } \\
\hline Total bilirubin $(\mu \mathrm{mol} / \mathrm{L})$ & 31 & -0.219 & 0.237 \\
\hline Direct bilirubin $(\mu \mathrm{mol} / \mathrm{L})$ & 31 & -0.228 & 0.218 \\
\hline Alanine aminotransferase (U/L) & 31 & -0.16 & 0.389 \\
\hline Aspartate aminotransferase (U/L) & 31 & -0.17 & 0.359 \\
\hline Alkaline phosphatase $(\mathrm{U} / \mathrm{L})$ & 31 & -0.192 & 0.301 \\
\hline Glutamyl transpeptidase (U/L) & 31 & -0.216 & 0.244 \\
\hline Fucosidase (U/L) & 31 & 0.049 & 0.792 \\
\hline Total bile acid $(\mu \mathrm{mol} / \mathrm{L})$ & 31 & -0.071 & 0.706 \\
\hline Pre-albumin (mg/L) & 31 & 0.362 & 0.045 \\
\hline Total protein $(\mathrm{g} / \mathrm{L})$ & 31 & 0.492 & 0.005 \\
\hline Albumin (g/L) & 31 & 0.1 & 0.592 \\
\hline PT (s) & 30 & -0.059 & 0.756 \\
\hline INR & 30 & -0.122 & 0.522 \\
\hline
\end{tabular}

PT: prothrombin time; INR: international normalized ratio. 